\title{
Reporting Obligation of Credit Card Transaction: Perspective of Bank Secrecy and the Government Regulation in Lieu of Law No 1/2017 on the Access to Information for Taxation Purposes
}

\author{
Acep Rohendi* \\ DOI: https://doi.org/10.22304/pjih.v5n1.a8
}

Submitted: December 15, 2017 | Accepted: May 2, 2018

\begin{abstract}
Prior to the issuance of the Government Regulation in Lieu of Law 1/2017, bank's secrecy is applied only to depositors or investors. The Government Regulation in Lieu of Law 1/2017 abolished the bank's secrecy for taxation purposes. According to the provisions of secrecy in Law on Banking, credit card transaction reporting is not bank's confidential, either before or after the birth of the Government Regulation in Lieu. Although not a bank confidential, the Bank Indonesia Law and the Financial Services Authority Law do not regulate or order the bank to report credit card data to the Directorate General of Taxation. The obligation exists after the Taxation Law were issued. As a lex specialist, the banking authorities need to be given the right to order banks to open access to information for taxation purposes. To avoid unlawful acts, banks need to create customer approval clauses for the purposes of opening credit card data in credit applications. This paper discusses the synchronization between the provisions of secrecy in the Laws relating Banking with the Government Regulation in Lieu of Law $1 / 2017$ in relation to the credit card report obligation. In addition, this paper triggered by the pros and the cons of the parties concerned, the assumption that bank secrecy and credit card data reporting obligation to tax institutions have a weak legal basis since they are opposed to the principle of lex specialist derogat lex generalis.
\end{abstract}

Keywords: bank confidentiality, credit card, tax report.

\section{Sinkronisasi antara Undang-Undang Perbankan pada Pasal-Pasal Rahasia Bank dengan Perpu No. 1 Tahun 2017 Tentang Akses Informasi untuk Kepentingan Perpajakan Terkait Kewajiban Pelaporan Kartu Kredit}

\begin{abstract}
Abstrak
Rahasia bank sebelum terbitnya Perpu 1/2017 hanya berlaku bagi nasabah penyimpan atau investor. Perpu 1/2017 menghapuskan sifat rahasia bank untuk kepentingan perpajakan. Pelaporan transaksi kartu kredit ditinjau dari ketentuan rahasia bank dalam UU perbankan adalah bukan rahasia bank. Baik sebelum ataupun sesudah lahirnya Perpu 1/2017. Meskipun bukan rahasia bank, baik UU BI maupun UU OJK tidak mengatur atau memerintah bank melaporkan data kartu kredit kepada Direktorat Jenderal Pajak dan adanya kewajiban bank tersebut setelah terbit peraturan pelaksanan UU Perpajakan. Sebagai lex spesialis baik otoritas perbankan perlu diberi hak memerintah bank atas keterbukaan akses informasi untuk perpajakan. Bank untuk menghindari gugatan perbuatan melawan hukum, maka dalam aplikasi permohonan kredit perlu klausul persetujuan nasabah untuk kepentingan

PADJADJARAN Journal of Law Volume 5 Number 1 Year 2018 [ISSN 2460-1543] [e-ISSN 2442-9325]

Faculty member of Universitas BSI, JI. Sekolah Internasional Nomor 1-6 Bandung, Indonesia, acep.aph@bsi. ac.id, S.H., M.H., Dr. (Universitas Padjadjaran), M.M. (Universitas ARS Internasional).
\end{abstract}


pembukaan data kartu kredit. Tulisan ini dipicu oleh pro kontra dari pihak-pihak terkait serta adanya anggapan sebagai rahasia bank, serta kewajiban pelaporan data kartu kredit oleh bank kepada institusi pajak mempunyai dasar hukum yang lemah sebab bertentangan dengan asas lex spesialis derogat lex generalis. Tulisan ini bermaksud membahas ketentuan rahasia bank di Indonesia, dan sinkronisasi antara UU Perbankan pada Pasal-Pasal Rahasia bank dengan Perpu Nomor 1 Tahun 2017 (Perpu 1/2017) terkait kewajiban pelaporan kartu kredit.

Kata kunci: kartu kredit, laporan perpajakan, rahasia bank.

\section{A. Introduction}

This research is based on the issuance of the Regulation of the Minister of Finance Number 39/PMK.03/2016 on the Fifth Amendment to the Regulation of the Minister of Finance Number 16/PMK.03/2013 on the Details of Data and Information Types and Procedures for Data and Information Delivery Related to Taxation (Minister of Finance Regulation 39/2016). The regulation has raised the pros and the cons. The government's expectation of these provisions has a positive impact on the increase of state revenues from the taxation sector. At least, there is addition of database that spearheads the state that requires citizens to pay their tax obligations to the state. Another reason is to provide access for the Directorate General of Taxes (DGT) to access data from credit card users. ${ }^{1}$

The issuance of the Minister of Finance Regulation 39/2016 requires financial institutions that issue credit card to report any data and credit card transactions to the DGT. Such data by the bank must be immediately reported in the direct form to the DGT as well as electronically (online) form no later than May 31, 2016. As stipulated in the Minister of Finance Regulation 39/2016 on March 22, 2016, ${ }^{2}$ any data and credit card transaction that must be reported to the DGT comes from the billing statement of credit card payment.

The obligation of banks to open customer data raises a debate. The disagreed party contends that if the customer's data is opened, it has potentials to be misused. The other opinion is that there are still prominent figures who interpret customer data as an impenetrable secret, except the data that is stated in the law expressly, for example, to be used on the purpose of criminal case investigation. ${ }^{3}$

Hukumonline.com, “PMK Data Kartu Kredit Berdampak Positif Penambahan Pendapatan Negara”, http://www. hukumonline.com/berita/baca/lt5710c9c7b82f3/pmk-data-kartu-kredit-berdampak-positif-penambahanpendapatan-negara, accessed on September 2017.

2 Ministry of Finance of Republic of Indonesia, “Lampiran Peraturan Menteri Keuangan Nomor 39/PMK.03/2016 tentang Perubahan Kelima atas Peraturan Menteri Keuangan Nomor 16/PMK.03/2013 tentang Rincian Jenis Data dan Informasi serta Tata Cara Penyampaian Data dan Informasi Yang Berkaitan Dengan Perpajakan", http://www.sjdih.depkeu.go.id/fulltext/2016/39 PMK.03 2016Per.pdf, downloaded on September 2017, pp. 93-95.

$3 \quad$ Hukumonline.com, "Bank Setuju Buka Nasabah untuk Pajak dengan Syarat: Transparansi sudah menjadi tren dunia perpajakan", http://www.hukumonline.com/berita/baca/lt56ce60b42c28d/bank-setuju-buka-nasabahuntuk-pajak-dengan-syarat, accessed on September 2017. 
The Association of National Commercial Banks (Perbanas -Perhimpunan Bankbank Umum Nasional) assesses that the opening of credit card transaction data to DGT cannot be done to all customers, but only for the customers that have problem. The opening of credit card transaction data by tax officials cannot be applied to all customers. The opening of transaction data is only for customers who allegedly have done tax evasion. ${ }^{4}$

The Indonesian Credit Card Association (AKKI-Asosiasi Kartu Kredit Indonesia) criticized the DGT's policy, which required banks to report credit card transaction data. The policy is considered as disturbing for customers, after the rise of credit card closures and the number of requests for credit limit declines. ${ }^{5}$ Bank Indonesia (BI) recorded the volume of credit card transactions in the first quarter of 2016 for 25.84 million, decreased for 3.59 percent compared to the same period in the previous year for 26.80 million. Meanwhile, from the nominal side, the transaction fell 6.77 percent from Rp 26.57 trillion to Rp 24.77 trillion. ${ }^{6}$ The Chairman of the Board of Commissioners of Financial Services Authority (OJK-Otoritas Jasa Keuangan), Muliaman D. Hadad, conveyed the same thing related to the decrease in transaction volume and credit card plafond. ${ }^{7}$

The Regulation of Bank Indonesia (BI) Number 2/19/PBI/2000 on the Requirements and Procedures for Ordering or Written Licenses to Open Bank Secrets (BI Regulation 2/2000) stipulates that information about depositors and customers' deposits is bank secrets, other than non-confidential depositors. ${ }^{8}$ Information on the depositary customers and customers deposits is not a bank secret in the case of taxation purposes. The most required aspect is to obtain orders or written permission to disclose bank secrets from the chairman of Bank Indonesia. ${ }^{9}$

There is the Regulation of the Government Number 31 of 2012 on the Release and Collection of Data and Information Relating to Taxation (Government Regulation 31/2012) as the implementing regulation of the Law Number 6 of 1983 on General Provisions and Procedures of Taxation (Taxation Law of 1983). Article 2(1) of the Government Regulation 31/2012 stipulates that government agencies, institutions, associations, and other parties are required to provide data and information relating to taxation submitted to the DGT. One party that is obliged to provide data and

\footnotetext{
Safyra Primadhyta, "Perbanas: Tidak Semua Data Kartu Kredit Nasabah Bisa Dibuka", http://www. cnnindonesia.com/ekonomi/20160330185047-92-120630/perbanas-tidak-semua-data-kartu-kredit-nasabahbisa-dibuka/, accessed on September 2017.

5 Christine Novita Nababan, "Tak Hanya BCA, Nasabah juga Tutup Kartu Kredit di Bank Lain”, http://www. cnnindonesia.com/ekonomi/20160517141621-78-131337/tak-hanya-bca-nasabah-juga-tutup-kartu-kredit-dibank-lain/, accessed on September 2017.

6 Ibid.

$7 \quad$ Ismed Eka Kusuma, “OJK: Transaksi Kartu Kredit Turun Akibat Kebijakan Wajib Lapor”, http://www.aktual.com/ ojk-transaksi-kartu-kredit-turun-akibat-kebijakan-wajib-lapor/, accessed on September 2017.

8 Article 2(1) and (2) of the Regulation of Bank Indonesia Number 2/19/PBI/2000 on Requirements and Procedures for Ordering or Written Licenses to Open Bank Secrets (BI Regulation 2/2000).

9 Article 2(4) in connection with Article 3 Paragraph (1) of the BI Regulation 2/2000.
} 
information as referred to in Article 2(1) of the Government Regulation 31/2012 is association, the banks. ${ }^{10}$

To support the success of state revenue from the tax sector, it seems that the government policy is not only limited to issue the Minister of Finance Regulation $39 / 2016$, which regulates the obligations of institutions/associations to convey data and information related to taxation. The government also issued a higher provision compared to the previous regulation, which is the Regulation of the Government in Lieu of Law (Perpu). It is the Regulation of the Government in Lieu of Law Number 1 of 2017 on the Access to Information for Taxation Purposes (Government Regulation in Lieu of Law 1/2017). There are at least some reasons for the government to issue the Government Regulation in Lieu of Law 1/2017. They are the existence of taxpayers who avoid taxes abroad, the existence of tax refuge/protection centers of taxation, the purpose of exchanging information between states, mandatory supervision on the implementation of tax obligations fulfillment based on the selfassessment system ${ }^{11}$, and to reveal the potential for large taxes due to "DGT data tax amnesty for the realization of repatriation of funds less than $15 \%$ of the target of Rp 1000 trillion".12

The Government Regulation in Lieu of Law 1/2017 revoked several articles concerning bank secrets in both conventional and sharia banking laws. The position equals to the Law, but it is still temporary and not yet permanent. The Government Regulation in Lieu of Law is the authority of the President which is granted by the Article 21(1) of the 1945 Constitution of the Republic of Indonesia (1945 Constitution). The article stipulates that in the crisis of force, the government can make regulation in lieu of law.

The Government Regulation in Lieu of Law $1 / 2017$ is temporary and not permanent since the provision of Article 21(2) of the 1945 Constitution requires a Government Regulation in Lieu of Law to obtain approval from the House of Representatives (DPR-Dewan Perwakilan Rakyat). Based on Article 21(2) of the 1945 Constitution, if the House of Representatives do not approve a Government Regulation in Lieu of Law, the Government Regulation in Lieu of Law must be revoked. This means that the articles on bank secrecy revoked in Article 8 of the Government Regulation in Lieu of Law 1/2017 become valid again.

Prior to the issuance of the Government Regulation in Lieu of Law 1/2017, bank secrecy is regulated in the Law Number 10 of 1998 on the Amendment to the Law Number 7 of 1992 on the Banking (Law on Banking of 1998). The implementation through BI Regulation 2/2000 is contradictory to the Article 2(1) of the Government

10 Article 3(1) of the Regulation of Government Number 31 of 2012 on the Release and Collection of Data and Information Relating to Taxation (Government Regulation 31/2012).

11 General Explanation of the Government Regulation in Lieu of Law Number 1 of 2017 on Access to Information for Taxation Purposes (Government Regulation in Lieu of Law 1/2017).

12 Muhammad Baidarus, "Perpu Nomor 1 Tahun 2017, Reformasi Perpajakan Indonesia Pasca Tax Amnesty?", https://www.kompasiana.com/muhammadbaidarusrespati/perpu-nomor-1-tahun-2017-reformasiperpajakan-indonesia-pasca-tax-amnesty 591d800d1cafbdc607b64886, accessed on September 2017. 
Regulation 31/2012. There should be further academic studies relating in this field, to discuss the synchronization and the scope of bank secrets between the Law on Banking of 1998 and BI Regulation 2/2000. The studies may also discuss the general provisions and procedures of Law Number 16 of 2009 on the Stipulation of Government Regulation in Lieu of Law Number 5 of 2008 on the Fourth Amendment to the Law Number 6 of 1983 on General Provisions and Procedures of Taxation (Taxation Law of 2009) and its implementation regulations, including the Government Regulation 31/2012 and the Minister of Finance Regulation 39/2016. In terms of limits and scope of subject (client/personal taxpayer) and object (data and information) related to credit card transaction data, Banks, previously, were not required to report to the DGT, unless they are requested with the permission from $\mathrm{BI}$.

Some laws that regulate banking do not regulate the opening of credit card transaction data. ${ }^{13}$ Therefore, the legal products made by the government for such needs should be in accordance with other related legal products. According to Bagir Manan, "The provisions found in the rules of general laws remain effective, except the rules are specified in the special law". ${ }^{14}$ The Law on Banking of 1998 can be lex specialist to other laws, which are lex generalis.

Legal provisions made by the Government should not be at the expense of the bank's credit card business, such as the decline in transaction volume, job losses, and sanctions, as well as the privacy of members of community who are not in trouble with taxation.

In Indonesia, as the legal state sourced to Pancasila, the legal products made must consider the balance of various legal interests that include the interests of individual, public, and the state. ${ }^{15}$ One should not sacrifice other interests. Law products are generally made to fulfill political interests of a highly dominant government. ${ }^{16}$ This is contrary to the status as a legal state. According to Satjipto Rahardjo, legal state can achieve the status of prosperous nation. ${ }^{17}$ There should not be community groups that feel overwhelmed by the expenditures, due to the enactment of a legal product made by the Government.

Related to the description, there are two issues to be discussed. They are the provisions of bank secrecy in Indonesia before and after the establishment of the Government Regulation in Lieu of Law 1/2017, as well as synchronization between

13 Ronald Waas, "Data Kartu Kredit Dijadikan Sumber Penelusuran Profil Wajib Pajak”, http://new.hukumonline. com/berita/baca/It56fe59ec04824/data-kartu-kredit-dijadikan-sumber-penelusuran-profil-wajib-pajak, accessed on September 2017.

14 Bagir Manan in A.A. Oka Mahendra, "Mengenai Asas Lex Specialis Derogat Legi Generalis", http://www. hukumonline.com/klinik/detail/lt509fb7e13bd25/mengenai-asas-lex-specialis-derogat-legi-generalis, accessed on September 2017.

15 See also Osgar S. Matompo in D. Pinasang, "Falsafah Pancasila Sebagai Norma Dasar (Grundnorm) dalam Rangka Pengembanan Sistem Hukum Nasional", Lentora Justice, Vol. 2, No. 1, 2015, pp.77-78.

16 See Suhariyono AR., "Kapita Selekta Sekitar Pembentukan Peraturan Perundang-Undangan", PERSPEKTIF, Vol. XV, No. 4, 2010, p. 389.

17 Satjipto Rahardjo, Hukum dan Perilaku: Hidup Baik adalah Dasar Hukum yang Baik, Jakarta: Kompas, 2009, p. viii. 
the bank secrecy provisions with the Government Regulation in Lieu of Law 1/2017 related to credit card reporting obligation. The purpose of this paper is to find a solution for credit card reporting by the bank to the DGT to have a strong legal basis and to make bank able to avoid lawsuits from customers who feel their legal interests violated.

\section{B. Bank Secrecy Regulations in Indonesia Before and After the Government Regulation in Lieu of Law 1/2017}

1. The Settings of Bank Secrecy before the Government Regulation in Lieu of Law $1 / 2017$

Banks that run conventional system operations are regulated in the Law on Banking of 1998. Banks that runs the operational system of sharia is regulated in Law Number 21 of 2008 on the Sharia Banking (Sharia Banking Law). Indonesian banking is originally supervised and fostered by Bank Indonesia (BI) pursuant to the Law Number 6 of 2009 on the Stipulation of the Regulation of the Government in Lieu of Law Number 2 of 2008 on the Second Amendment to the Law Number 23 of 1999 on the Bank Indonesia to be a Law (BI Law of 2009). ${ }^{18}$

The authority of $\mathrm{BI}$ in fostering and supervising banks is replaced by a new institution in Indonesian banking, namely the Financial Services Authority (OJK) with the legal basis set forth in the Law Number 21 of 2011 on the Financial Services Authority (OJK Law). As of December 31, 2013, the functions, duties, and authorities of fostering and supervising financial services activities in the banking sector have been shifted from $\mathrm{BI}$ to OJK. ${ }^{19}$ The regulation does not cover the tasks of regulating and maintaining the smoothness of the payment system that are still the tasks of $\mathrm{BI},{ }^{20}$ including the arrangement and supervision of credit cards.

The Law on Banking of 1998 as well as the Sharia Banking Law stipulates bank secrecy in its legislation. The bank's secrecy arrangement is a continuation of previous banking laws governing bank secrecy, which are the Law Number 7 of 1992 on the Banking (Law on Banking of 1992), the Law Number 14 of 1967 on Principles of Banking (Law on Banking of 1967), and the Government Regulation in Lieu of Law Number 23 of 1960 on the Bank Secrecy (Government Regulation in Lieu of Law 23/1960). All these regulations are the frontrunner of bank secrecy in Indonesia.

The regulations of bank secrecy in Indonesia indicate the existence of state protection of bank customers. On the other hand, from the banking side, bank secrecy is one form of protection of banking institutions to its customers. The

18 See Article 8(c) of the Law Number 6 of 2009 on the Stipulation of Regulation of the Government in Lieu of Law Number 2 of 2008 on The Second Amendment to the Law Number 23 of 1999 on Bank Indonesia to become a Law (BI Law of 2009); Article 29(1) of the Law Number 10 of 1998 on the Amendment to the Law Number 7 of 1992 on Banking (Law on Banking of 1992); Article 50 of the Law Number 21 of 2008 on Sharia Banking (Sharia Banking Law).

19 Article 5 of the Law Number 21 of 2011 on Financial Service Authority.

20 Payment system is a system that includes a set of rules, institutions, and mechanisms, which are used to carry out the transfer of funds to meet an obligation arising from an economic activity (Article 1(6) of the BI Law of 2009). 
existence of customer protection from bank institutions to gain public trust since bank is an institution that is people's partner in the storage of money or partners in loans. In economics view, the function of money is a means of wealth storing or store of value ${ }^{21}$, so that the wealth of a person needs to get protection from banks, both as depositor and borrower.

The Law on Banking of 1998 specifies bank secrecy, which reads "bank secrets are anything related to information about depositors and customers". 22 This understanding is related to the differentiation of customer definitions embraced in the Law on Banking of 1998. The law divides into two types customers: depositors and debtors. The depositor customer is defined as "the customer who places the funds in the bank in the form of deposits based on agreement between the bank and the respective customer". ${ }^{23}$ The debtor customers are defined as "the customer who obtains credit or financing facilities under the Sharia Principles or equivalent based on agreement between the bank and the respective customer". ${ }^{24}$

The theory of bank secrecy includes the absolute nature of bank secrecy. The bank secrecy theory is relative. ${ }^{25}$ According to the first bank secrecy theory, bank is required to uphold customers' secrets without exception. Bank is required to hold their customers' secrets to anyone, including public interest (state) or private interest (bank/client/heirs). The second theory, the bank remains obliged to hold firm the secrets of customers but it is not absolute obligation because in certain circumstances customer data can be opened. ${ }^{26}$ Bank is required to hold secrets but it is not absolute obligation, if the interests of the state or other interests established by law require it to be disregarded.

Indonesia today adheres the relative bank secrecy theory. The Law on Banking of 1998 only regulates the protection of depositor customer. It is a renewal of the previous regime adopted in the Law on Banking of 1992, which protected two sides of customers (depositors and debtors). It does not distinguish between depositors and debtors as stated in Article 1(16) of the Law on Banking of 1992, which reads "Bank secrets are all things related to finance and other matters of bank customers, which according to the prevalence of the banking world, shall be kept confidential". The BI Regulation 2/2000 confirms that "a customer, other than a Depositor Customer, shall not constitute an information that shall be kept confidential by the Bank". The birth of the Law on Banking of 1998 reduced $^{27}$ the category of bank secrecy from the

21 Frederic S. Mishkin, The Economic of Money, Banking and Financial Market, $7^{\text {th }}$ edition, Boston: AddisonWesley, 2004, p. 47.

Article 1(28) of the Law on Banking of 1992.

Article 1(17) of the Law on Banking of 1992.

Article 1(18) of the Law on Banking of 1992.

Muhamad Djumhana, Hukum di Perbankan Indonesia, Bandung: PT Citra Aditya Bakti, 2006, p.172.

Ibid.

The definition of the word reduksi (reduction) in the Great Dictionary of the Indonesian Language of the Language Center (KBBI) is discount /deduction, deduction (of price and so on), https://kbbi.kemdikbud.go.id/ entri/reduksi, accessed on September 2017. 
Law on Banking of 1992, from the originally protecting both depositor and debtor customers to only the depositors (including savings).

Muhamad Djumhana argues that the renewal of the bank's confidentiality provisions in the Law on Banking of 1992 that is amended by the Law on Banking of 1998 was due to the abuse of bank secrecy by bad debtors, bad-faith parties, unlawful actors, and discourage of information exchange for interested parties. ${ }^{28}$ Unfortunately, this opinion is too generalizing and, vice versa, does not assume the bank debtor who is honest, vigilant, and does not commit acts against the law.

The reduction of bank secrecy is inconsistent with the theory of law objectives in line with the Utilitarian Philosophy (the principle of the greatest happiness for the greatest number of utilitarian philosophy) ${ }^{29}$ that law aims to provide the greatest protection to the majority of society. Such reduction seems to contradict the principle of prudence in an Indonesian idiom "karena nila setitik rusak susu sebelangga" (a small dust breaks a pot of milk). The crime of a handful of unscrupulous debtors must be beard by all customers.

Unlike conventional Laws relating banking, the Sharia Banking Law divides customers into three customers: depositor, investor, and recipient customers. First, the depositor customer is the customer who deposits funds in a Sharia Bank and/ or Sharia Business Unit in the form of Deposit based on an agreement between the Sharia Bank or the Sharia Business Unit and the respective customer. ${ }^{30}$ Second, investor customer is a customer who places fund in Sharia Bank and/or Sharia Business Unit in the form of investment based on an agreement between the Sharia Bank Syariah or the Sharia Business Unit and the respective customer. ${ }^{31}$ Third, the facility recipient customer is a customer who obtains a fund facility or equivalent, based on Sharia Principles. ${ }^{32}$

The Sharia Banking Law defines the bank secrecy wider, it does not cover only depositor customer, but also investor customer. Article 1(14) of the Sharia Banking Law reads: "Bank secrecy is anything related to information concerning the depositors and their deposits and investors and their investments." The Sharia Banking Law differentiates the depositor and investor customers based on an 'akad' (an agreement based on Islamic Sharia Principles) which between the customer and the bank.

Article 1(13) of the Sharia Banking Law reads "An akad is a written agreement between a Sharia (Islamic) Bank or a Sharia Business Unit and any other party which contains rights and obligations for each party in accordance with Sharia Principles". An akad is a contract between one party and another, both parties are bound by

\footnotetext{
Muhamad Djumhana, Op.cit., p. 171.

Mark Tebit, Philosophy Of Law: An Indroduction, $2^{\text {nd }}$ edition, London: Routledge, 2005, p. 131.

Article 1(17) of the Law on Banking of 1992

Article 1(18) of the Law on Banking of 1992.

Article 1(19) of the Law on Banking of 1992.
} 
the agreement they make. ${ }^{33}$ This distinction is due to the different relationships between the bank and its customers. The agreement between the depositors and the bank is based on wadiah contract, while the agreement between the investors and the bank is based on mudhrabah contract. ${ }^{34}$ In connection with the principal activities of bank, which includes collecting funds from the community in the form of savings/investments and channeling them back to the community in the form of credit or other financing facilities, bank provides protection for the customers, while the customers who receive the financing facilities from bank are not protected.

Based on the General Explanation of the Law on Banking of 1998, the elimination of debtor customers from bank secrecy coverage is an attempt to improve the function of social control over Banking institutions', ${ }^{35}$ which is felt to be very closed. The Law on Banking of 1998 still recognizes the existence of bank secrecy in order to ensure public trust as a public fund manager. However, it does not cover all customer data. In other words, not all data are considered to be confidential.

Bank secrecy in sharia banking is stipulated in the Article 40(1) of the Law on Banking of 1998 which reads "Banks are required to keep confidential information about the depositor customer and their savings, except in the case as referred to in article 41, article 41A, article 42, article 43, article 44, and article 44A". The meaning 'except' in this article means that bank secrecy, which include depositors and deposits, may be breached by their interests by the interests set forth in Article 40(1) of the Law on Banking of 1998.

The interests that can exclude bank secrecy in Article 40 of the Law on Banking of 1998 are as follows:

1. Public interest, namely interests of the state/general interest, including the interests of taxation (Article 41), the interests of state receivables/auctions/State Debt Committee (Article $41 \mathrm{~A}$ ), and the interests of criminal justice (Article 42). Removal of the bank secrecy is also affirmed in Article 42A, which reads "Banks are required to provide information as referred to in Article 41, Article 41A, and Article 42". This means that banks are required to provide customer and deposit data for taxation purposes (Article 41), interests of state receivables/auctions/ State Debt Committee (Article 41A), and the interest of criminal justice (Article $42)$, so with this obligation the interests are called the public interest.

2. Private interests, namely interests related to the interests of the bank/interest concerning the interests of the customer (client/heirs), including the interests of civil cases between bank and its customers (Article 43), the interest of exchange

33 Adiwarman Karim, Bank Islam: Analisis Fikih dan Keuangannya, Jakarta: PT RajaGrafindo Persada, 2004, p. 57

34 Khotobul Umam, Trend Pembentukan Bank Umum Syariah: Pasca Undang-Undang Nomor 21 Tahun 2008 (Konsep, Regulasi dan Implementasi, Yogyakarta: BPFE, 2009, p. 47. Akad Wadiah is an agreement of custodian of goods or money between parties, who have goods, or money, and parties who are trusted with the aim to maintain safety, security, and the integrity of the goods or the money. Akad mudhrabah in collecting funds is an agreement of partnership between first party (malik, shahibul mal, or the customer as the owner of the fund) and second party ('amil, mudharib, or sharia bank as a fund manager) by dividing business profits in accordance with the agreement set forth in contract.

35 General Explanation of the Law on Banking of 1992. 
of information between banks (Article 44) (Article 44A(1)) and the interests of the heirs of depositors (Article 44A(2)).

The bank secrecy scope in sharia banking is regulated in Articles 40 to 49 of the Sharia Banking Law. Article 41 of the Sharia Banking Law reads: "Banks and Affiliated Parties shall keep confidential information about the Depositor Customers and their Deposits and Investor Customer and their Investments. Similar to the Law on Banking of 1998, the customers who are covered by bank secrecy are the customers from the funding side. While from the lending side of the funds are not protected by the bank secrecy provisions.

The interests that can eliminate the bank secrecy to the depositor customer and the deposit and investor customer and investment are regulated in Article 43 to 48 of the Sharia Banking Law are as follows:

1. Public interest, namely the interest of tax criminal investigation (Article 42), the interest of criminal justice (Article 43). Removal of the bank secrecy is also affirmed in Article 44, which reads, "Banks are required to provide information as referred to in Article 42 and Article 43". This means that bank is required to provide data of depositor customers and their deposits and investor customers and their investments for the interests of tax criminal investigation (Article 41), and the interests of criminal justice (Article 43). In contrast to the Law on Banking of 1998, the interests of state receivables and auctions/State Debt Management Committee are not included. Another difference of taxation interests in the Sharia Banking Law is specifically mentioned as the interest of tax criminal investigation (Article 42).

2. Private interest, namely the interest of civil cases between bank and its customers (Article 45), the interests of exchange of information between banks (Article 46), the interests of depositor/investor customers (Article 47) and the interests of the heirs of depositors/investors (Article 48).

Outside of the Banking Law, there are public interests set forth in laws that may reveal bank secrecy as follows:

1. The interest in eradicating corruption (Article 12c of the Law Number 30 of 2002 on the Corruption Eradication Commission (KPK))

2. Interest in taxation (Article 35(2) of the Taxation Law of 2009).

3. The importance of preventing and eradicating money laundering crime (Article 45 of the Law Number 8 of 2010 on the Prevention and Eradication of Money Laundering Criminal).

4. The interest in preventing and eradicating terrorism financing (Article 16 of the Law Number 9 of 2013 on the Prevention and Eradication of Criminal Acts of Terrorism Financing).

Outside of Laws relating banking, there is private interest regulated in laws that may disclose bank secrets. It is confirmation interest in fund transfer transactions that is regulated in Article 6 of the Law Number 3 of 2011 on Fund Transfers that 
banks can provide information on transfer recipients. It excludes bank secrecy related to the need for confirmation in the transfer of funds made electronically. It was concluded that Indonesian banking legislation embraces the bank secrecy theory both on conventional banking and sharia banking laws.

\section{The Settings of Bank Secrecy after the Government Regulation in Lieu of Law $1 / 2017$}

The President issued the Government Regulation in Lieu of Law 1/2017 on May 8, 2017 for the taxation purposes. It is also to fulfill the commitment of international agreement in the field of taxation. Article 1 of the Government Regulation in Lieu of Law 1/2017 reads:

"Access to financial information for the taxation purposes includes access to receive and obtain financial information in the framework of implementation of the provisions of the laws and regulations in the field of taxation and the implementation of international agreements in the field of taxation".

The essence of Government Regulation in Lieu of Law 1/2017 is the obligation of banks to provide reports of clients to the Director General of Taxes in two forms of reports containing financial statements, which include the following: ${ }^{36}$

1. Financial statements for the importance of the exchange of financial information based on international agreement standard in the field of taxation. International agreements in the field of taxation include the Agreement on the Avoidance of Double Taxation, the Agreement for the Exchange Information on Taxation Exchange Agreement, the Convention on Mutual Administrative Assistance in Tax Matters. ${ }^{37}$

2. Financial statements for the purposes of taxation. The obligation of bank to report financial information of customer to the Director General of Tax is related to identity of the account holder; financial account number; identity of financial service institution; balance or value of financial account; and income associated with financial account. ${ }^{38}$ Banks are also prohibited from serving the opening of new financial accounts for new customers, or a new transaction, related to a financial account for an existing customer; refusing to comply with the financial account identification provisions.

In order to support the smoothness of the DGT in obtaining banking data, the barriers that complicates their duties in obtaining data from the Bank is eliminated by revoking the bank secrecy provisions. Therefore, to request a report of customer, the Director General of Tax no longer needs to ask for BI or OJK permission. The intended customers are the depositor customer in conventional banks, and the investor customers in sharia banks.

Article 2(2) and (1) of the Government Regulation in Lieu of Law 1/2017.

Explanation of Article 2(1) of the Government Regulation in Lieu of Law 1/2017.

38 Article 1(3) of the Government Regulation in Lieu of Law 1/2017. 
Meanwhile bank secrecy provisions that are revoked by the Government Regulation in Lieu of Law 1/2017, are Article 40 and Article 41 of the Law on Banking of 1998; and Article 41 and 42 of the Sharia Banking Law.

The implication of the revocation is that the current customer data from the funding side is not a secret anymore as long as it is used for the benefit of tax reports. At the same time, it is also revoked by Article 35(2) of the Government Regulation in Lieu of Law 1/2017 and Article 35A of the Taxation Law of 1983 that has already been amended several times. This article is related to the opening of bank secrecy upon written request of the Minister of Finance.

The revocation of bank secrecy provisions in Indonesian banks both in conventional and sharia banks by the Government Regulation in Lieu of Law 1/2017 for the purposes of tax reporting eliminates the confidentiality of securities regulated in banking legislation. It can be said that, in the latest developments, the secrecy regime of banks in Indonesia that adheres to the relative theory has changed to the 'zero theory' since there is no longer bank secrecy after the birth of the Government Regulation in Lieu of Law $1 / 2017$ for the purposes of taxation reporting. ${ }^{39}$ Currently, the Director General of Taxes no longer requires the permission of the Minister of Finance to obtain bank customer data.

The absence of client protection for civil rights is incompatible with the theory of interest protection in the science of law. The protection of self-interest is one of the three main functions of law, according to Roscoe Pound. ${ }^{40}$ Another legitimate interest to be protected is the public and the state interests. The harmonious balance of the implementation of these three interests is the essence of justice. ${ }^{41}$ Justice, which is the value and the philosophy of community life, is a legal goal in accordance with the ultimate goal of state and community life. ${ }^{42}$

The development that is currently focused on infrastructure development is physical. It tends to decelerate the implementation of human rights. ${ }^{43}$ The existence of the Government Regulation in Lieu of Law 1/2017 is one of the indicators since it eliminates the confidentiality of bank customer data for taxation purposes. The customer data, however, is a private property that is protected by articles concerning Human Rights in the protection of property rights, especially in Article $28 \mathrm{H}(4)$ of the 1945 Constitution. It is true that taxation for the interests of the state should also be regulated by laws (Article 23A of the 1945 Constitution) but its implementation should take into account Article $28 \mathrm{H}(4)$ of the 1945 Constitution. John Locke argues that the State is constituted by its people, but the natural rights of the people

\footnotetext{
Article 1 of the Government Regulation in Lieu of Law 1/2017.

Lili Rasjidi and I.B. Wiyasa Putra, Hukum Sebagai Suatu Sistem, Bandung: Mandar Maju, 2003, p. 123.

Atip Latipulhayat, "Roscoe Pound", PADJADJARAN Jurnal Ilmu Hukum, Vol. 1, No. 2, 2014, p. 415.

Asep Warlan Yusuf, "Hukum dan Keadilan”, PADJADJARAN Jurnal Ilmu Hukum, Vol. 2, No. 1, 2015, p. 1.

Atip Latipulhayat, "Editorial: Merawat Hak Asasi Manusia”, PADJADJARAN Jurnal Ilmu Hukum, Vol. 3, No. 3, 2006, p. 2.
} 
(the right to life, to liberty, and to property) shall not be disturbed or confiscated by the State. ${ }^{44}$

B. The Synchronization between the Provisions of Secrecy in the Law on Banking and the Government Regulation in Lieu of Law 1/2017 about Access to Information for Taxation Purposes in Relation to Credit Card Reporting Obligation

1. Credit Card Transaction Reporting to DGT in the Perspective of Bank Secrecy

Credit card is one of conventional general bank business services as mentioned in Article 6(1) of the Law on Banking of 1998. Article 13 of this law regulates that, other types of banks, such as the BPR (Bank Perkreditan Rakyat-A type of bank that specifically operates in rural area) has no credit card business service. On the contrary, Sharia Banking Law does not mention the term credit card. However, Article 13 of the Sharia Banking Law explains that there is a term of 'financing card' in the business arrangement of Sharia Commercial Bank. Furthermore, Article 19 (h) of the Sharia Banking Law reads "performing activities of debit card and/or financing card based on Sharia Principles ".

Credit card is known as a kind of plastic card that is used as a means of payment or cash withdrawal. Initially, it is made for the purpose of practical considerations, so when someone goes for traveling, he/she does not need to carry much money. In addition, it can be used for various transactions such as paying various bills. ${ }^{45}$ The existence of a credit card allows the credit card carriers (customers) not to bring large amounts of money in shopping or traveling.

There is no further explanation for credit card or financing card found in the Indonesian law. Credit card arrangements can be found in the Regulation of Bank Indonesia Number 11/11/PBI/2009 on the Implementation of Card-Based Payment Instrument Activity. It was later updated by the Regulation of Bank Indonesia number 14/2/PBI/2012 on the Amendment to the Regulation of Bank Indonesia Number 11/11/PBI/2009 on the Implementation of Card-Based Payment Instrument Activity (BI Regulation 14/2012).

Although the BI Regulation 14/2012 regulates credit card, it applies to both credit cards issued by conventional bank and financing card issued by sharia bank. This is indicated in the Consideration Chapter of the Regulation that includes both the Law on Banking and the Sharia Banking Law. It is reinforced by Article 1(1) of the BI Regulation 14/2012 that the definition of bank covers both conventional bank and sharia bank. Similarly, Article 1(4) of the Regulation defines credit card in a neutral sense, not to mention any credit cards with bank's interests because it does not comply with Islamic Sharia.

44 Bagir Manan and Susi Dwi Harijanti, "Konstitusi dan Hak Asasi Manusia”, PADJADJARAN Jurnal Ilmu Hukum, Vol. 3, No. 3, 2016, p. 450.

45 See Sigit Triandaru and Totok Budi Santoso, Bank dan Lembaga Keuangan Lain, Jakarta: Salemba Empat, 2008, p. 254. 
The interest in credit card transactions is considered haram in Sharia because it contains elements of usury. On the contrary, in the financing card issued by Sharia Bank does not contain elements of usury. ${ }^{46}$ Credit card issued by conventional bank is used for consumption needs; whereas Islamic financing card issued by sharia bank is used for productive needs. ${ }^{47}$

Credit card issued by conventional bank is considered a credit agreement between bank and debtor customer since it make the incurrence of accounts payable $^{48}$ between the customer and the bank as set out in Article 1(4) of the $\mathrm{BI}$ Regulation 14/2012. If a credit card is used by a conventional bank customer as a means of payment in carrying out an expense transaction, the bank shall pay to the seller of goods. Then, in the time specified, the customer pays back the money to the bank without interest.

The benefit of credit card for banks is that to make sure public funds stored in the banks. In this case, the funds of goods seller that serve the credit card payments will remain be stored in the bank that issue the credit cards. Therefore, although in the opening there is a flow of bailout funds from bank on behalf of credit card holder to the seller, in fact there is no physical money flow from the bank to the seller of goods paid by the credit card.

The different concept is found in the cash advance by credit card, bank charges interest in addition to cash drawn. It is purely a loan from the bank to the credit card holder from the time of the cash withdrawal. This cash withdrawal transaction is a "pure" credit from a credit card issuing bank to a credit card holder. In reality, there is a physical cash flow from banks to credit card holders in the amount of funds withdrawn by credit card. It fulfills the elements of credit as set out in Article 1(11) of the Law on Banking of 1998.

In view of Article 1(4) of the BI Regulation 14/2012, the elements of credit card include the existence of the card as a means of payment/cash withdrawal, the obligation to be paid by the cardholder arising from economic transaction and credit elements (Article 1(11) of the Law on Banking of 1998regulates that bank provides bailout funds), the existence of loan and lending agreement, the obligation of cardholder to pay off debt at maturity.

Credit card, according to General Explanation of the BI Regulation 14/2012, is a means of payment with funds sourced from credit or financing. The difference with ordinary credit that does not use a card is that credit by credit card does not automatically charge interest. The credit cardholder repays the debt to the bank on the payment period at maturity. Interest is charged by bank to credit user, in case of delinquent payment after maturity. BI has also set a maximum limit of interest imposition. ${ }^{49}$

\footnotetext{
Nining Wahyuningsih, "Kartu Kredit (Suatu Tinjauan Syariat Islam)", Jurnal Kajian Ekonomi dan Perbankan Syariah, Vol. 5, No. 2, 2013, p.1.

lbid.

48 lbid., p. 8.

$49 \quad$ Article 17 of the BI Regulation 2/2000.
} 
The credit card holder who uses the card to make transactions or withdraw cash is categorized as debtor customer ${ }^{50}$ since the holder obtains credit facility based on a credit agreement between the bank and the customer.

In sharia banking, a customer who makes payment by financing card issued by sharia bank is also categorized as customer who receives financing facility. ${ }^{51}$ Sharia bank provides loan funds as financing in the form of lending and borrowing transactions in the form of receivables qardh. ${ }^{52}$

The definition of bank secrecy in Article 1(28) of the Law on Banking of 1998 covers only depositors and deposits. Bank secrecy provisions in Article 40 also consider credit card users as customers who are covered by bank secrecy. It is because the protection meant by the secrecy provisions of that article is depositors and deposits. This means that based on Article 40 of the Law on Banking of 1998, credit card holders' identity or loan amount are not confidential.

The same point is applied in financing card. The definition of bank secrecy in Article 1(14) of the Sharia Banking Law only recognizes depositors and deposits as the bank secrets. Further, Article 41 of the Law on Banking of 1998 regulates that customers of financing card is not considered as the customers who are covered by bank secrecy provisions that only cover depositors and deposits. This means that based on this article the card holder, both the identity and the amount of loan, is not bank's secret.

Based on the bank secrecy provisions in both conventional and sharia banking, bank has no ties to conceal data related to credit card transactions and financing cards. The obligation to keep secret data and credit card information appears in the BI Regulation 14/2012 only covers the following:

1. Article $13(1)(d)$ regulates the existence of an obligation to keep data and information from the supporting service parties in the field of information technology and system in implementing card-based payment instrument.

2. Article $21(1)(c)$ regulates the obligation to request the requirement to conceal data and information from the supporting service parties (document delivery service companies, sales agents, or debt collection services).

Based on these provisions, $\mathrm{BI}$ requires the bank to ask the supporting service parties to request to make data and information related to credit card holders as secret. However, for the banks themselves, in the BI Regulation 14/2012, there is no requirement to keep bank secrets against credit card institutions. The assertion is stipulated by the bank secrecy provision in Article 2(2) of the BI Regulation 2/2000 that "information concerning customers other than depositors is not an information that shall be kept confidential by Bank". The information causes banks not to keep data and credit information confidential. Nevertheless, for bank security from the demands of bank customers in the future upon the opening of bank secrets, then

Article 1(18) of the Law on Banking of 1992.

Article 1(19) of the Sharia Banking Law.

52 Article 1(25) of the Sharia Banking Law. 
as Tarsisius Murwadji suggests, the opening agreement of bank secret is made in a separate document in addition to the application agreement document or the opening of deposits or placement of funds in the bank. It is advisable that this bank opening agreement is an inseparable agreement in the application of opening deposit or placement of bank funds, no need to separate the documents. This is necessary, in line with the Verdict of the Supreme Court Number 404 K/Pdt.Sus-BPSK/2017. ${ }^{53}$ The essence of the Supreme Court's decision is that the credit agreement between customer and bank is stronger than the Decision of the Consumer Dispute Board that is regulated in the Law Number 8 of 1998 on the Consumer Protection. ${ }^{54}$

There is no provision in the BI Regulation 14/2012 that regulates BI has the right to provide data and information related credit cards to the DGT. However, the provisions of transaction data transparency of credit card in the Minister of Finance Regulation 39/2016 require banks to report data and credit card transactions to the DGT. There is also Article 2 Paragraph (2) and Article 3 Paragraph (3) of the Government Regulation 31/2012 that stipulate the obligation of banks to report Data and Information related to taxation to DGT.

On the one hand, BI does not require bank to keep credit card data confidential. On the other hand, the BI Regulation 14/2012 does not contain the right of BI to report credit card transaction data or contain bank obligation to report data and credit card transactions either to $\mathrm{BI}$ or to external party -in this case, the DGT. The existence of the obligation to report credit card as stipulated in the Minister of Finance Regulation 39/2016 does not cover the obligation to report credit card data and transactions of customers. It should be noted that in the field of banking, the highest authority related to credit card now is Bl. Although there is OJK, in accordance with Article 4(2) and Article 8(b) of the BI Law of 2009, ${ }^{55}$ a task of BI is to "manage and control payment system".

The Regulation of Bank Indonesia is a legal product of a special state institution, which is a specialist, as a rule of conduct to the Laws relating banking and BI Law. It cannot be ruled out by parallel legal products as the executor of a law. ${ }^{56}$ The Minister of Finance Regulation 39/2016, although parallel, cannot rule out the BI Regulation $14 / 2012$ because the Regulation of the Minister of Finance is a generalist law.

53 Tarsisius Murwadji, “Antisipasi Pelarian Dana Asing ke Luar Negeri Melalui Perlindungan Kontraktual Pembukaan Rahasia Bank", PADJADJARAN Jurnal IImu Hukum, Vol. 2, No. 2, 2015, http://pjih.fh.unpad.ac.id/wp-content/ uploads/2015/09/2-edited-pre-final.pdf, accessed on May 2016, p. 248.

54 The Decree of the Supreme Court Number 404 K/Pdt.Sus-BPSK/2017, https://putusan.mahkamahagung.go.id/ pengadilan/mahkamah-agung/direktori/perdata-khusus/perlindungan-konsumen/, accessed on November 2017.

55 "Bank Indonesia is an independent state institution that, in carrying out its duties and authorities, is free from interference by the Government and/or other parties, except for matters expressly provided in this Law".

56 Paundra Galih Rakhasiwi, Retno Ardiyani Kusumaningrum, and Ristis Handika, "Sinkronisasi Peraturan Bank Indonesia Nomor: 14/8/PBI/2012 dengan Undang-Undang Nomor 40 Tahun 2007 dan Peraturan Pemerintah Nomor 29 Tahun 1999 dalam Pelaksanaan Akuisi Perbankan", Privat Law, Vol. 3, No. 1, 2013, pp. 73-74. 


\section{Credit Card Transaction Reporting to DGT in the Perspective of the Government Regulation in Lieu of Law 1/2017}

The essence of the Government Regulation in Lieu of Law 1/2017 is to revoke the provisions that limit access to financial information for DGT. It covers some institutions like banks, banks, and capital markets. The goal is to facilitate the DGT to get financial information from these institutions, which so far there are procedures and requirements to obtain financial data. Some taxpayers disobey the obligation to report their revenues and assets by utilizing restricted DGT's access on such institutions. This condition inhibits the realization of effective tax forgiveness policy and the strengthening of the database for taxation purposes. There is also a concern that Indonesia can be a potential destination country for illegal fund placement. ${ }^{57}$

Several articles about bank secrecy in both conventional and sharia banking regulations become obstacles to the implementation of access to financial information for taxation purposes. The Government Regulation in Lieu of Law $1 / 2017$ revokes them. The provisions of bank secrecy in the conventional banking regulations that have been revoked by the Article 8(1) of the Government Regulation in Lieu of Law 1/2017 are Article 40 and Article 41 of the Law on Banking of 1998. The provisions of bank secrecy in the sharia banking regulations that have been revoked by the Article 8(5) of the Government Regulation in Lieu of Law 1/2017 are Article 41 and Article 42 of the Sharia Banking Law.

The issuance of the Government Regulation in Lieu of Law 1/2017 has revoked bank secrecy provisions for taxation purposes in both conventional and sharia banking. However, it does not have a significant effect on the provisions of credit cards that are regulated by the BI Regulation 14/2012 because credit card is not included bank secret. Bank secrets only cover depositor customers and deposits. The Government Regulation in Lieu of Law 1/2017 gives impacts if it requires data of depositor customer and deposit. The Government Regulation in Lieu of Law 1/2017 only breaks through the removal of the license of the Minister of Finance if it there is need to open data of depositor customer and deposits.

Previously, the technical term to open bank secrets was stipulated in Article 4 of the BI Regulation 2/2000 that, for the interest of taxation, the BI leaders are authorized to issue a written order to the bank to disclose the bank data of depositors to the tax officials. BI can issue a written order to bank upon written request from the Minister of Finance. Legally, from March 31, 2017, the obligation to report credit card transaction data by 23 banks in Indonesia becomes valid again. The fact is that it is contrary to the BI Regulation 14/2012 as lex specialist. Thereby, it reduces legal certainty if it is still implemented by banks. It is also prone to cause lawsuit from the card holder, as it is not regulated and mutually agreed in the credit card opening application. Customers who are disadvantaged either morally or materially can sue as regulated under Article 1365 of the Indonesian Code of Civil Law.

57 See the Explanation of the Government Regulation in Lieu of Law 1/2017. 
There is a contradiction between the obligation to report credit card transaction data to the DGT stipulated in the Minister of Finance Regulation 39/2016, which is a lex generalis, and the absence of Bl's obligation to instruct Bank to report credit card transaction data to DGT in the BI Regulation 14/2012, which is lex specialis as a BI Law implementation. Based on the adagium lex specialis derogate generalis, then the Minister of Finance Regulation 39/2016 cannot rule out the BI Regulation 14/2012. As a result, the legal basis for the obligation to report credit card transaction data to the DGT is a weak legal basis. This finding is in accordance with the essence of the Verdict of the Supreme Court Number 404 K/Pdt.Sus-BPSK/2017 that the status of special law (the BI Law) as lex specialis and general regulations as lex generalis, so that the principle lex specialist derogate lex generalis is applied.

\section{Conclusion}

The provisions of bank secrecy in Indonesia prior to the emergence of the Government Regulation in Lieu of Law 1/2017 in both conventional and sharia banking laws were only applied to the depositor customer and deposit, and investor customer and investment. The provisions governing interests that can eliminate the confidential nature of bank to depositor customer, deposit, investor customer and investment are governed both inside as well as outside the Laws relating banking. Prior to the issuance of the Government Regulation in Lieu of Law 1/2017, some articles concerning bank secrecy in both conventional and sharia banking were revoked. The data of funding side customer is no longer a bank secret for the benefit of the taxation report.

The synchronization between the provisions of secrecy in the Laws relating banking and the Government Regulation in Lieu of Law 1/2017 can be performed by giving the right to the banking authority ( $\mathrm{BI}$ and OJK) to make articles in the form of an implementation regulations requiring the bank to report to tax authorities. This purpose can be achieved by changing the regulations of the BI or OJK institutions.

\section{References}

Books

Adiwarman Karim, Bank Islam: Analisis Fikih dan Keuangannya, PT Raja Grafindo Persada, Jakarta, 2004.

Khotobul Umam, Trend Pembentukan Bank Umum Syariah: Pasca Undang-Undang Nomor 21 Tahun 2008 (Konsep, Regulasi dan Implementasi), BPFE, Yogyakarta, 2009.

Lili Rasjidi dan I.B. Wiyasa Putra, Hukum Sebagai Suatu Sistem, Mandar Maju, Bandung, 2003.

Mishkin, Frederic S., The Economic of Money, Banking and Financial Market, Addison-Wesley, Boston, 2004.

Muhamad Djumhana, Hukum Perbankan di Indonesia, PT Citra Aditya Bakti, Bandung, 2006. 
Satjipto Rahardjo, Hukum dan Perilaku: Hidup Baik adalah Dasar Hukum yang Baik, Kompas, Jakarta, 2009.

Sigit Triandaru dan Totok Budi Santoso, Bank dan Lembaga Keuangan Lain, Salemba Empat, Jakarta, 2008.

Soerjono Soekanto dan Sri Mamudji, Penelitian Hukum Normatif: Suatu Tinjauan Singkat, PT Raja Grafindo Persada, Jakarta, 2011.

Tebit, Mark, Philosophy of Law: An Indroduction, $2^{\text {nd }}$ edition, Routledge, London, 2005.

\section{Other Documents}

A.A. Oka Mahendra, "Mengenai Asas Lex Specialis Derogat Legi Generalis", hukumonline.com, http://www.hukumonline.com/klinik/detail/ It509fb7e13bd25/mengenai-asas-lex-specialis-derogat-legi-generalis, accessed on September 2017.

Asep Warlan Yusuf, "Hukum dan Keadilan", PADJADJARAN Jurnal IImu Hukum, Vol. 2, No. 1, 2015.

Atip Latipulhayat, "Roscoe Pound", PADJADJARAN Jurnal Ilmu Hukum, Vol. 1, No. 2, 2014.

, "Editorial: Merawat Hak Asasi Manusia", PADJADJARAN Jurnal Ilmu Hukum, Vol. 3, No. 3, 2006.

Bagir Manan and Susi Dwi Harijanti, "Konstitusi dan Hak Asasi Manusia", PADJADJARAN Jurnal IImu Hukum, Vol. 3, No. 3, 2016.

Christine Novita Nababan, "Tak Hanya BCA, Nasabah juga Tutup Kartu Kredit di Bank Lain", http://www.cnnindonesia.com/ekonomi/20160517141621-78-131337/ tak-hanya-bca-nasabah-juga-tutup-kartu-kredit-di-bank-lain/, accessed on September 2017.

D. Pinasang, "Falsafah Pancasila Sebagai Norma Dasar (Grundnorm) dalam Rangka Pengembanan Sistem Hukum Nasional", Lentora Justice, Vol. 2, No. 1, 2015.

Great Dictionary of the Indonesian Language of the Language Center (KBBI), https:// kbbi.kemdikbud.go.id/entri/reduksi, accessed on September 2017.

Hukumonline.com, "PMK Data Kartu Kredit Berdampak Positif Penambahan Pendapatan Negara", http://www.hukumonline.com/berita/baca/ It5710c9c7b82f3/pmk-data-kartu-kredit-berdampak-positif-penambahanpendapatan-negara, accessed on September 2017.

"Bank Setuju Buka Nasabah untuk Pajak dengan Syarat: Transparansi sudah menjadi tren dunia perpajakan", http://www.hukumonline. com/berita/baca/It56ce60b42c28d/bank-setuju-buka-nasabah-untuk-pajakdengan-syarat, accessed on September 2017.

Ismed Eka Kusuma, "OJK: Transaksi Kartu Kredit Turun Akibat Kebijakan Wajib Lapor", http://www.aktual.com/ojk-transaksi-kartu-kredit-turun-akibat-kebijakanwajib-lapor/, accessed on September 2017. 
Minister of Finance of Republic of Indonesia, "Lampiran Peraturan Menteri Keuangan Nomor 39/PMK.03/2016 tentang Perubahan Kelima atas Peraturan Menteri Keuangan Nomor 16/PMK.03/2013 tentang Rincian Jenis Data dan Informasi serta Tata Cara Penyampaian Data dan Informasi Yang Berkaitan Dengan Perpajakan", http://www.sjdih.depkeu.go.id/fulltext/2016/39 PMK.03 2016Per.pdf, downloaded on September 2017.

Muhammad Baidarus, "PERPU Nomor 1 Tahun 2017, Reformasi Perpajakan Indonesia Pasca Tax Amnesty?", https://www.kompasiana.com/ muhammadbaidarusrespati/PERPU-nomor-1-tahun-2017-reformasiperpajakan-indonesia-pasca-tax-amnesty 591d800d1cafbdc607b64886, accessed on September 2017.

Nining Wahyuningsih, "Kartu Kredit (Suatu Tinjauan Syariat Islam)", Jurnal Kajian Ekonomi dan Perbankan Syariah, Vol. 5, No. 2, 2013.

Safyra Primadhyta, "Perbanas: Tidak Semua Data Kartu Kredit Nasabah Bisa Dibuka", http://www.cnnindonesia.com/ekonomi/20160330185047-92-120630/ perbanas-tidak-semua-data-kartu-kredit-nasabah-bisa-dibuka/, accessed on September 2017.

Suhariyono AR., "Kapita Selekta Sekitar Pembentukan Peraturan PerundangUndangan", PERSPEKTIF, Vol. XV, No. 4, 2010.

Tarsisius Murwadji, "Antisipasi Pelarian Dana Asing ke Luar Negeri Melalui Perlindungan Kontraktual Pembukaan Rahasia Bank", PADJADJARAN Jurnal IImu Hukum, Vol. 2, No. 2, 2015.

\section{Legal Documents}

The 1945 Constitution of the Republic of Indonesia.

Indonesian Code of Civil Law.

Law Number 6 of 1983 on General Provisions and Procedures of Taxation.

Law Number 7 of 1992 on the Banking.

Law Number 8 of 1998 on the Consumer Protection.

Law Number 10 of 1998 on the Amendment to the Law Number 7 of 1992 on the Banking.

Law Number 30 of 2002 on the Corruption Eradication Commission.

Law Number 21 of 2008 on the Sharia Banking.

Law Number 6 of 2009 on the Stipulation of the Regulation of the Government in Lieu of Law Number 2 of 2008 on the Second Amendment to the Law Number 23 of 1999 on the Bank Indonesia to be a Law.

Law Number 8 of 2010 on the Prevention and Eradication of Money Laundering Criminal.

Law Number 3 of 2011 on Fund Transfers.

Law Number 21 of 2011 on the Financial Services Authority. 
Law Number 9 of 2013 on the Prevention and Eradication of Criminal Acts of Terrorism Financing.

Regulation of the Government in Lieu of Law Number 1 of 2017 on the Access to Financial Information for Taxation Purposes.

Regulation of the Government Number 31 of 2012 on the Release and Collection of Data and Information Relating to Taxation.

Regulation of Bank Indonesia Number 2/19/PBI/2000 on the Requirements and Procedures for Ordering or Written Licenses to Open Bank Secrets.

Regulation of Bank Indonesia Number 14/2/PBI/2012 on the Amendment to the Regulation of Bank Indonesia Number 11/11/PBI/2009 on the Implementation of Card-Based Payment Instrument Activities.

Regulation of the Minister of Finance Number 39/PMK.03/2016 on the Fifth Amendment to the Regulation of the Minister of Finance Number 16/ PMK.03/2013 on the Details of Data and Information Types and Procedures for Data and Information Delivery Related to Taxation.

Verdict of the Supreme Court Number 404 K/Pdt.Sus-BPSK/2017. 